PALEONTOLOGICAL NOTE

\title{
How many species of the aquatic sloth Thalassocnus (Xenarthra: Megatheriidae) were in Chile?: new evidences from the Bahía Inglesa Formation, with a reappraisal of their biochronological affinities
}

\author{
Javiera Peralta-Prato ${ }^{1},{ }^{*}$ Andrés Solórzano ${ }^{2}$ \\ ${ }^{I}$ Facultad de Ciencias Naturales y Oceanográficas, Universidad de Concepción, Barrio Universitario s/n, Casilla 160-C, Concepción, Chile. \\ javivalepera@gmail.com \\ ${ }^{2}$ Programa de Doctorado en Ciencias Geológicas, Facultad de Ciencias Químicas, Universidad de Concepción, Barrio Universitario \\ s/n, Casilla 160-C, Concepción, Chile. \\ solorzanoandres@gmail.com \\ *Corresponding author: solorzanoandres@gmail.com
}

\begin{abstract}
The aquatic sloth, Thalassocnus, is one of the most intriguing lineage of mammal known from the southern pacific coast of South America during the late Neogene. It was initially recognized in Perú, but recent paleontological surveys also recorded its presence in Chile. However, the determination of how many species of Thalassocnus were actually present in Chile remains as an open question. Here, we provide a detailed morphological description of an isolated distal fragment of humerus recovered at the Mina Fosforita member ( $c a .7 \mathrm{Ma}$ ), Bahía Inglesa Formation (Atacama Region, northern Chile), which is referred to Thalassocnus. Morphological comparisons with others forms from Chile and Perú allow us to attribute the $\mathrm{CPUC} / \mathrm{C} / 557$ specimen to Thalassocnus $\mathrm{cf}$. T. natans, though some degree of intraspecific variation is acknowledged. The assessment of the stratigraphic provenance of the materials with previously assigned to Thalassocnus from the Bahía Inglesa, Horcón and Coquimbo formations, permits us to propose that the taxonomic diversity of Thalassocnus in Chile is unequivocal conformed by T. carolomartini, and T. natans. We also admitted the likely presence of T. antiquus and probably T. yaucensis. Futures discoveries of more complete specimens, and/or the detailed analysis of undescribed specimens from Chile will undoubtedly contribute to illustrate the evolutionary history of the Thalassocnus radiation in Chile.
\end{abstract}

Keywords: Bahia Inglesa Formation, Neogene, Thalassocnus, Sloths, Chile.

RESUMEN. ¿Cuántas especies del perezoso acuático Thalassocnus (Xenarthra: Megatheriidae) existieron en Chile?: nuevas evidencias de la Formación Bahía Inglesa, con una revisión de sus afinidades biocronológicas. El perezoso acuático, Thalassocnus, representa uno de los linajes de mamíferos más intrigantes presentes en la costa Pacífica del sur de Sudamérica durante el final del Neógeno. Inicialmente fue reconocido en Perú, pero estudios paleontológicos recientes han demostrado su presencia en Chile. Sin embargo, la determinación de cuántas especies de Thalassocnus habitaron este país no está bien delimitada. En el presente trabajo se realizó una descripción morfológica detallada de un fragmento distal aislado de húmero colectado en el miembro Mina Fosforita ( ca. $7 \mathrm{Ma}$ ), de la Formación Bahía Inglesa (región de Atacama, norte de Chile), el cual se refiere al género Thalassocnus. Comparaciones morfológicas con otras formas de Chile y Perú nos permiten atribuir el espécimen estudiado (CPUC/C/557) a Thalassocnus cf. T. natans, no obstante, se reconoce cierto grado de variación intraespecífica. Una revisión de la procedencia estratigráfica de los materiales asignados a Thalassocnus colectados en las formaciones Bahía Inglesa, Horcón y Coquimbo nos permite proponer que la diversidad taxonómica del género en Chile está conformada de manera inequívoca por T. carolomartini y T. natans. También admitimos la posible presencia de T. antiquus y probablemente T. yaucensis. Futuros descubrimientos de especímenes más completos, y/o el análisis detallado de especímenes colectados (pero no descritos) en Chile, sin duda contribuirán a ilustrar la historia evolutiva de la radiación de Thalassocnus en Chile. 


\section{Introduction}

The modern sloths (Xenarthra: Folivora) are a group of mammals native to South America with strictly arboreal habits (Vizcaíno and Loughry, 2008). Nevertheless, sloths have a long evolutionary history in South America, with some taxa dispersed later into Central and North America and the Antillean Islands (e.g., McDonald, 2005; Rincón et al., 2018). The earliest putative sloth, Pseudoglyptodon, comes from the late Eocene of Cerro Blanco, Argentina (McKenna et al., 2006; Gaudin and Croft, 2015). But taxonomic and ecological diversification of sloths began during the Oligocene (Deseadan SALMA) with several distinct lineages represented at this time (Pujos et al., 2007; McDonald and De Iuliis, 2008; Shockey and Anaya, 2011). The fossil record of North and South America reveals that sloths were extremely diverse in terms of the number of genera (more than 90 named genera, McKenna and Bell, 1997; Wilson and Reeder, 2005), range of body sizes, as well as distinctive locomotives adaptations, which is a reflection of the variety of habitats in which they lived (Muizon and McDonald, 1995; White, 1997; McDonald, 2005; McDonald and De Iuliis; 2008, Shockey and Anaya, 2011; Toledo et al., 2014), including arboreal (Pujos et al., 2007), fossorial (Bargo et al., 2000), scavenging (Fariña and Blanco, 1996) and aquatic habits. The last adaptation, unique among sloths, has been suggested for the genus Thalassocnus (Muizon and McDonald, 1995; Amson et al., 2014, 2015a, b, c).

This genus, initially described based on cranial and postcranial remains from the Pisco Formation (late Miocene to Pliocene in age) in the Sacaco area (Perú), was referred to the subfamily Nothrotheriinae (Muizon and McDonald, 1995). However, recent phylogenetic analysis suggest that it is clustered amongst the Megatheriidae (Amson et al., 2016). Currently, five species of Thalassocnus are recognized based in materials recovered from successive horizons, including: T. antiquus Muizon et al., 2003 ( 8 to $8.8 \mathrm{Ma}$; Late Miocene), T. natans Muizon and McDonald, 1995 (ca. 7.30 Ma; Late Miocene), T. littoralis McDonald and Muizon, 2002 (7.1 to 5.93 Ma; Late Miocene), T. carolomartini McDonald and Muizon, 2002 (ca. 3.9 Ma Ma; Early Pliocene) and T. yaucensis Muizon et al., 2004 (Early Pliocene) (McDonald and Muizon, 2002; Muizon et al., 2003, 2004a, 2004b; Amson et al., 2014, 2015a, b, c; De Los
Arcos et al., 2017; C. de Muizon, personal communication, 2018). All of these species were described on the basis of remains found in the Pisco Formation (Perú). In this Formation, Thalassocnus remains are associated with marine invertebrates and vertebrates that inhabit coastal marine environments (Muizon and DeVries, 1985; Bianucci et al., 2016). In part because of these taphonomic conditions, it was initially suggested that Thalassocnus was probably adapted to aquatic or semi-aquatic environments (Muizon and McDonald, 1995). Later studies demonstrated the progressive increase of osteosclerosis and pachyostosis through time along the lineage, reminiscent of that observed in some marine mammals (Amson et al., 2014). Thalassocnus likely fed on marine vegetation within the water, possibly forced by the desert nature of the Peruvian coast during the Neogene (Muizon and McDonald, 1995; Amson et al., 2014; Amson et al., 2015a, b, c).

Although the most complete specimens of Thalassocnus comes from the Pisco Formation (Perú), remains belonging to this taxon have also been found in marine-coastal deposits of the Neogene of Chile (Canto et al., 2002, 2008; Suárez et al., 2011; Pyenson et al., 2014; De los Arcos et al., 2017). These records were initially given in the Bahía Inglesa Formation, and more recently in the Coquimbo and Horcón Formations, representing the southernmost record of the genus, previously considered endemic to Perú (Canto et al., 2008; Muizon et al., 2003; De los Arcos et al., 2017). To date, distinct species of the aquatic sloth Thalassocnus have been mentioned in Chile including: T. natans (Suárez et al., 2011; Pyenson et al., 2014), T. carolomartini (De los Arcos et al., 2017), a form similar to T. antiquus or T. natans (Canto et al., 2008), an intermediate form between T. littoralis and T. natans (Suárez et al., 2011), and one of the species of Thalassocnus younger than T. natans (De los Arcos et al., 2017). However, the material reported in some cases has not been described in detail or even illustrated (e.g., Suarez et al., 2011; Pyenson et al., 2014), limiting our understanding of the taxonomic diversity of Thalassocnus in Chile. As a consequence, in contrast to the outstanding fossil record from Perú, a definitive determination of how many species of Thalassocnus inhabited Chile during the Neogene remains an open question.

The collection of the Geological Museum "Lajos Biró Bagóczky" of the Universidad de Concepción (Biobío Region, Chile) contains an isolated fragment 
of humerus from the Bahía Inglesa Formation that shows morphological affinities with Thalassocnus. The main goals of this work are to provide a detailed description of this specimen, put the recognized finding of Thalassocnus in Chile in chronological framework, and reappraise the taxonomic diversity of the clade in Chile.

\section{Geological context}

The Bahía Inglesa Formation forms a clastic and semi-consolidated sequence of Middle Miocene to Late Pliocene age, deposited in different sedimentary environments ranging from rocky shoreline to upper continental slope (Marquardt et al., 2000; Achurra, 2004; Le Roux et al., 2016). The main outcrops of the unit are found on the coast of the Atacama Region (around $27^{\circ} \mathrm{S}$, Chile; e.g., Le Roux et al., 2016). Bahía Inglesa Formation is highly fossiliferous, presenting different stratigraphic levels with abundant marine vertebrates (e.g., Walsh and Hume, 2001; Suárez et al., 2004; Chávez, 2007, 2008) and invertebrates (Marchant et al., 2000). This Formation was formerly divided into three members, Morro, Bonebed and Lechero (Walsh and Suárez, 2005).
But recent studies have divided the formation, from base to top, in nine members: El Pimiento, Puerto Viejo, Punta Totoral, Cerro Ballena, La Higuera, Chorrillos, Mina Fosforita, Rocas Negras and Quebrada Blanca (see Le Roux et al., 2016 for details). The specimen described here comes from outcrops near to the cities of Bahía Inglesa (Fig. 1), probably from the mine "La Fosforita" (M. Suárez, personal communication, 2017), which belongs to the member Mina Fosforita. This member exhibits the greatest variability of depositional environments in the Bahía Inglesa Formation, ranging from the upper shoreface to the upper continental slope (see Le Roux et al., 2016 for details). The Mina Fosforita Member ( $c a .7$ $\mathrm{Ma}$; Late Miocene) is characterized, among others, by the occurrence of abundant shark teeth and cetacean bones in successions of thick clay-rich sandstones (see Le Roux et al., 2016 for details).

\section{Materials and methods}

The material studied is deposited in the Geological Museum “Lajos Biró Bagóczky”, Universidad de Concepción, Concepción (Chile). The measurements were taken using a digital caliper and were expressed
A

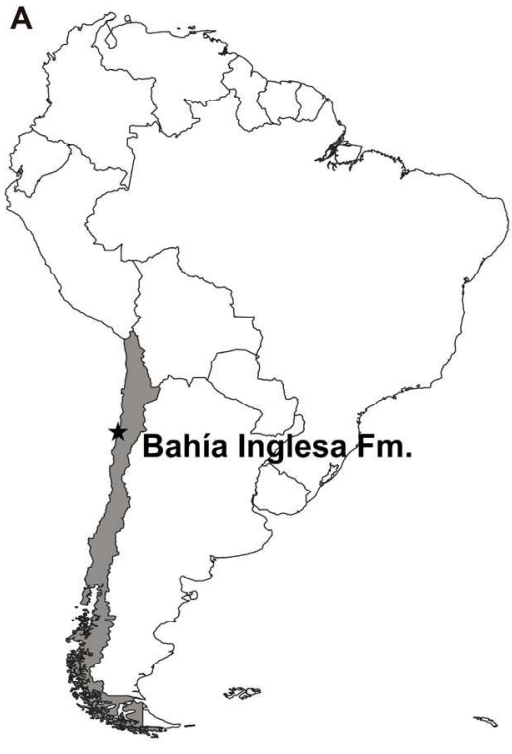

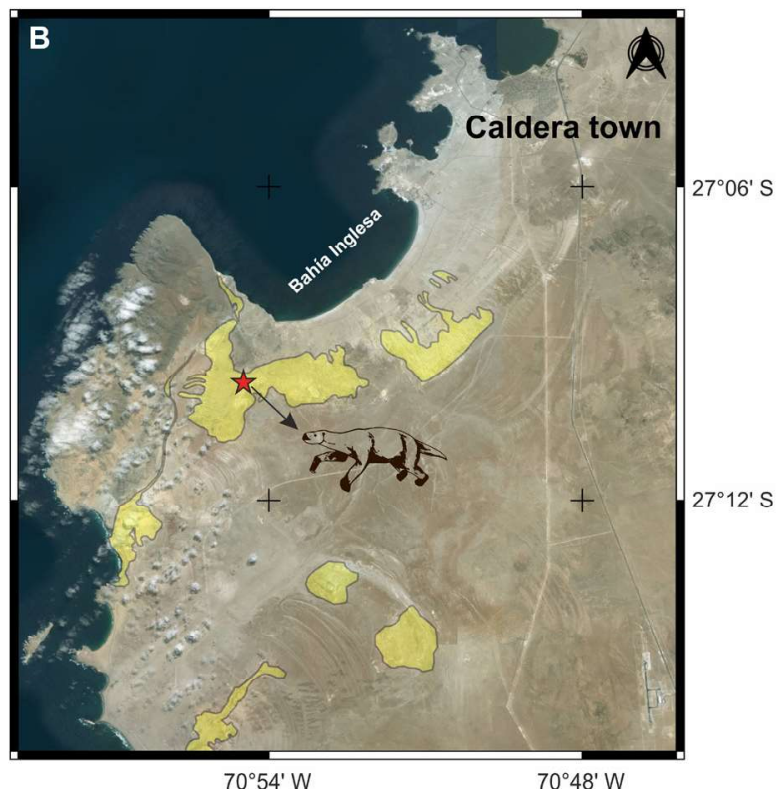

FIG. 1. Geographical and geological settings of the Bahía Inglesa Formation, Atacama Region, northern Chile ( $\left.27^{\circ} \mathrm{S}\right)$. A. Continental (black star indicates the location of the study area) and B. regional geographic provenance of the specimen CPUC/C/557 (red star). The pale yellow polygons in $\mathbf{B}$ indicates the outcrops of the Bahia Inglesa Formation near to the Caldera town (based on Godoy et al., 2003). 
in millimeters $(\mathrm{mm})$. We followed the humerus osteological nomenclature proposed by Amson et al. (2015a). The comparisons were made from previous descriptions of Thalassocnus species found in the literature and extensively reviewed recently (e.g., Amson et al., 2014, 2015a, b, c; 2016; De los Arcos et al., 2017).

Institutional abbreviations. CPUC, Colección Paleontológica de la Universidad de Concepción, Concepción, Chile; SGO.PV, Museo Nacional de Historia Natural, Santiago de Chile, Chile; MPC, Museo Paleontológico de Caldera, Caldera, Chile

\section{Systematic paleontology}

Order Xenarthra Cope, 1889

Suborder Folivora Delsuc, Catzeflis, Stanhope, Douzery 2001 (=Tardigrada Latham and Davies, 1795).

Infraorder Megatheria McKenna and Bell, 1997 Family Megatheriidae Gray, 1821 Subfamily Thalassocninae Muizon, McDonald, Salas and Urbina, 2004

Thalassocnus Muizon and McDonald, 1995

Thalassocnus ef. T. natans Muizon and McDonald, 1995

Referred material. CPUC/C/557, a well-preserved distal fragment of a right humerus, with an eroded entepicondylar crest.

Locality and age. The specimen here described was collected in 1973 by the Professor Lajos Biró Bagóczky in beds of the Member Mina Fosforita, Bahía Inglesa Formation (unfortunately without further details). According to Le Roux et al. (2016) this member has an estimated age of 6.3-7.6 Ma (Late Miocene).

Description. In anterior view, the distal portion of the deltoid, pectoral and brachiocephalic crests are preserved (Fig. 2A). The brachiocephalic crest is present in the four latest species but absent in T. antiquus (Amson et al., 2015a). The junction of these crests, is elevated above the shaft in lateral view (Fig. 2D), this elevation is similar to that observed in other Thalassocnus spp. (Amson et al., 2015a). The deltoid crest is less expanded laterally than in T. littoralis (Amson et al., 2015a). A well-developed and rounded lateral epicondyle is positioned lateroproximally to the capitulum: in anterior view, the distal surface of the lateral epicondyle is more proximal than the distal edge of the capitulum, showing a clear step between both surfaces. As a consequence, a sulcus is present between the medial edge of the lateral epicondyle and the lateral edge of the capitulum, as is observed in T. antiquus and T. natans (Amson et al., 2015a). The lateral-most edge of the epicondylar ridge is rather parallel to the humerus shaft (Fig. 2A). The epicondylar ridge is not laterally expanded as in Nothrotheriops, neither compressed as in T. yaucensis (a consequence of the small size of the lateral epicondyle in the latter taxon), resembling T. littoralis than earlier species (Fig. 2A). The radial fossa is partially filled with sediment, but appears to be shallow (resembling T. yaucensis) and oval in shape (resembling all Thalassocnus spp. except $T$. yaucensis; Fig. 2A; Amson et al., 2015a). Its proximal margin is located towards the perpendicular edge of the epicondylar ridge (Fig. 2A). The proximal curvature of the epicondylar ridge begins between the distal junction of the deltoid, pectoral and brachiocephalic crests and the proximal tip of the radial fossa (Fig. 2A). In anterior view, the medial epicondyle is rounded and lies close to the distal end of the humerus. The medial edge of the medial epicondyle slopes slightly proximally (Fig. 2A), being similar to T. yaucensis and T. antiquus, but unlike T. littoralis and T. natans, in which it slopes distally or is parallel to the shaft, respectively (Amson et al., 2015a). The transverse expansion between the epicondyles is roughly symmetrical (Fig. 2A), a condition that is not observed in T. yaucencis (Amson et al., 2015a). Because the medial edge of the medial epicondyle slopes distally in T. littoralis, we considered the transverse expansion of the epicondyles as asymmetrical in this taxon, a condition that does not occur in T. carolomartini, in which it is roughly symmetrical (De los Arcos et al., 2017).

On the distal articular surface, in anterior view, a hemispherical capitulum and a flattened anteromedial part of the trochlea (Amson et al., 2015a) are observed. The capitulum is mainly limited to the antero-distal surface of the humerus and narrows distally with no extension on the posterior surface (Fig. 2A, B). The antero-proximal edge of the capitulum is convex and slightly proximal to the antero-proximal edge of the trochlea (Fig. 2A). In anterior and distal views, the capitulum and the trochlea are separated by a "V"shaped groove (Fig. 2A), forming an angle of $c a$. $125^{\circ}$ (Fig. 2E); resembling to T. natans, but unlike T. littoralis and T. yaucensis, in which the groove 


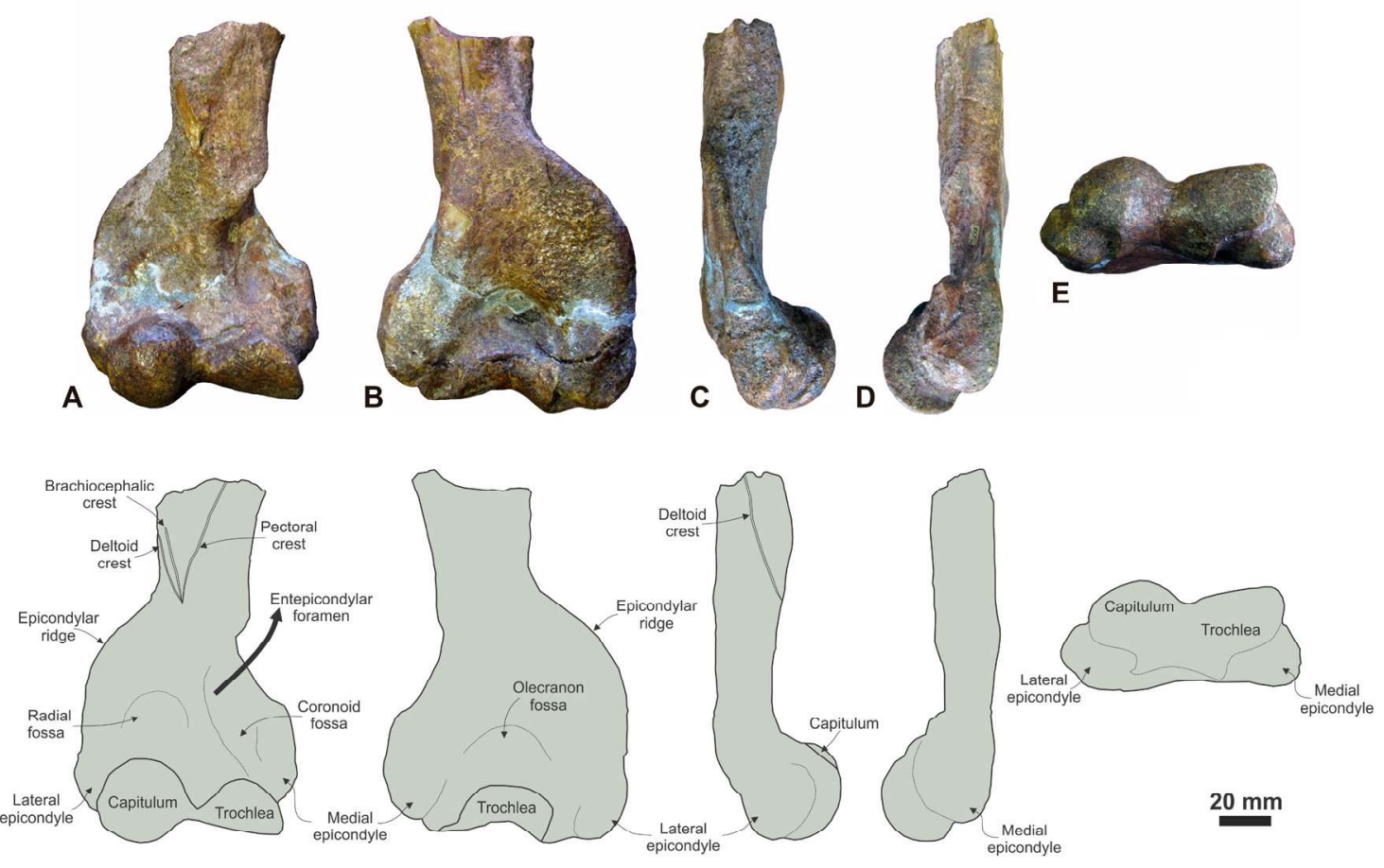

FIG. 2. Photographs (upper) and schematic drawings (lower) of the distal fragment of right humerus of Thalassocnus cf. T. natans $(\mathrm{CPUC} / \mathrm{C} / 557)$ from the Bahía Inglesa Formation (Chile), in anterior (A), posterior (B), lateral (C), medial (D) and distal (E) views.

is narrower (Amson et al., 2015a). The surface formed by the distal edge of the trochlea is slightly tilted distally (Fig. 2A), being similar to T. natans and T. antiquus. In anterior view, the coronoid fossa expands distomedially towards the proximal edge of the medial epicondyle. Is not possible to observe the proximal shape of the coronoid fossa because of the erosion of the entepicondylar bar (Fig. 2A). The coronoid fossa is separated from the radial fossa by a low ridge (Fig. 2A).

In posterior view, the medial epicondyle is distinctively narrow, mostly resembling $T$. antiquus (Fig. 2B), while it is broader in latter species (T. natans and T. littoralis) (Amson et al., 2015a). The distal edge of the medial epicondyle is not aligned with the distal edge of the trochlea (Fig. 2B, E), as occurs in T. antiquus. Both are separated by a wide and deep groove which extends on the posterior surface of the humerus proximally to the distomedial area of the olecranon fossa. This groove borders all the medial edge of the trochlea (Fig. 2B, D, E). It appears to be similarly developed in T. antiquus, but less so in later species (Amson et $a l ., 2015 a)$. In posterior view, the medial and lateral edges of the trochlea are subparallel, as is observed in T. littoralis, but unlike earlier species (Amson et al., 2015a). The proximal edge of the trochlea is wide $(31 \mathrm{~mm})$, roughly rectangular in shape, and forms the distal margin of the olecranon fossa (Fig. 2B). The olecranon fossa is deep, broad, and rounded; it is slightly wider than the trochlea (Fig. 2B). This fossa is not uniformly excavated. The latero-distal two-thirds are more excavated than the rest of the fossa, while in the medio-proximal third a shallower sub-fossa is observed, separated from lateral subfossa by a narrow ridge (Fig. 2B). In lateral view, the epiphysis is slightly displaced anteriorly $\left(\mathrm{c} .10^{\circ}\right)$ relative to the humerus shaft, while in the other Thalassocnus species this feature is less conspicuous (e.g., Amson et al., 2015a).

The epiphysis of CPUC/C/557 (Fig. 2), totally fused to the diaphysis indicates an adult individual. The proximo-distal length of the humerus fragment is $135 \mathrm{~mm}$, while the proximo-distal length between the distal joint of the deltoid, pectoral and brachiocephalic crests and the distal surface of the humerus is 85 $\mathrm{mm}$. Amson et al. (2015a) suggest that the junction of these crest is located approximately at the distal 
two-thirds of the shaft. Accordingly, the estimated proximo-distal length of the complete humerus (CPUC/C/557) must be $\sim 255 \mathrm{~mm}$. This length is similar to those reported for T. natans, and in the range of size of $T$. littoralis (Amson et al., 2015a). In $\mathrm{CPUC} / \mathrm{C} / 557$, the distal medio-lateral width between the large tuberosities is $84.7 \mathrm{~mm}$, being rather similar to those of T. yaucensis, and definitely narrower than the four other species especially compared with $T$. natans and T. littoralis (Amson et al., 2015a). The medio-lateral distal articular surface (capitulum plus the trochlea) is $65.2 \mathrm{~mm}$ width, being within the size range observed for the other species, except $T$. carolomartini $(83.6 \mathrm{~mm})$, which is apparently the largest known species (Amson et al., 2015a). The proportion between the medio-lateral distal articular surface and epicondylar width is 1.3 in CPUC/C/557, being smaller than other Thalassocnus spp. (Table 1). In addition, if we considered accurate the estimation of the proximo-distal humerus length of $\mathrm{CPUC} / \mathrm{C} / 557$, the proportion between it and the epicondylar width would be 3 , while in other Thalassocnus spp. range between 2.4-2.7 (no data for the two younger species; Table 1). These proportions suggest that in CPUC/C/557 the epicondylar width is smaller than in other recognized Thalassocnus species, excepting T. yaucensis.

Remarks. The combination of the following features: entepicondylar foramen (possessed by all Notrotheriidae and some Megatheriidae), rounded and distally positioned medial epicondyle allows us to refer the specimen $\mathrm{CPUC} / \mathrm{C} / 557$ to the genus Thalassocnus (Amson et al., 2015a; Amson et al., 2016). The only Thalassocnus humerus described from Chile, has been referred to T. carolomartini (De los Arcos et al., 2017). Although the specimen is partially prepared, it is possible to observe the transverse width of the distal end, the reduction of the medial epicondyle, and the symmetry of the distal epiphysis (De los Arcos et al., 2017). CPUC/C/557 clearly differs from this humerus in having medial and lateral epicondyles more proximally placed, and an epicondylar ridge almost parallel to the humerus shaft (Fig. 2A, B).

In terms of the specific affinity of CPUC/C/557, certain morphological characters allow us to distinguish it from the some of the recognized forms of Thalassoncus. In anterior view, CPUC/C/557, $T$. natans and T. littoralis have a brachiocephalic crest, whereas it is absent in T. antiquus (no data are available in T. yaucensis and T. carolomartini; Amson et al., 2015a). In anterior view, the lateral edge of the trochlea is distinctly tilted distally, as in T. natans and T. antiquus, but unlike later species (Amson $e t$ al., 2015a; De los Arcos et al., 2017). The proximal junction area between the capitulum and trochlea in CPUC/C/557 is a wide "V" shaped groove, as in $T$. natans; while in T. littoralis the groove is narrower, and in T. yaucencis and T. antiquus the groove is almost absent (Amson et al., 2015a). In posterior view, the distal edge of the medial epicondyle is well proximal to the distal edge of the trochlea, a

TABLE 1. MEASUREMENTS (IN MILLIMETERS) OF THE DISTAL PORTION OFTHE HUMERUS (CPUC/C/557) OF THALASSOCNUS CF. T. NATANS RECOVERED FROM THE BAHÍA INGLESA FORMATION, AND OTHER THALASSOCNUS SPP. (BASED IN THE DATA OF AMSON ET AL., 2015a).

\begin{tabular}{|c|c|c|c|c|c|c|c|c|}
\hline Measurement & T. antiquus & $\begin{array}{c}T . \\
\text { natans }\end{array}$ & $\begin{array}{c}\text { T. littoralis } \\
\text { (mean; } n=7)\end{array}$ & $\begin{array}{l}\text { T. littoralis } \\
\text { (min; } n=7 \text { ) }\end{array}$ & $\begin{array}{l}\text { T. littoralis } \\
(\max ; n=7)\end{array}$ & T. carolomartini & T. yaucensis & CPUC/C/557 \\
\hline Greatest PD length (A) & 245 & 255,4 & 251,1 & 227,0 & 284,0 & 297 & - & $255^{*}$ \\
\hline $\begin{array}{l}\text { Distal tuberosities, } \\
\text { greatest ML width (B) }\end{array}$ & 91 & 104,2 & 102,5 & 91,3 & 116,1 & $<120^{*}$ & 87,8 & 84,7 \\
\hline $\begin{array}{l}\text { Distal articular surface, } \\
\text { ML width (C) }\end{array}$ & 66,5 & 67,6 & 67,2 & 58,1 & 75,5 & 83,6 & 62,6 & 65,2 \\
\hline Proportion (A)/(B) & 2,69 & 2,45 & 2,45 & 2,49 & 2,45 & - & - & 3,01 \\
\hline Proportion $(\mathrm{B}) /(\mathrm{C})$ & 1,37 & 1,54 & 1,53 & 1,57 & 1,54 & - & 1,40 & 1,30 \\
\hline Proportion (A)/(C) & 3,68 & 3,78 & 3,74 & 3,91 & 3,76 & 3,55 & - & 3,91 \\
\hline
\end{tabular}

Abreviations: PD: proximodistal; ML: mediolateral; *: estimated measurement. 
trait reminiscent of T. natans and T. littoralis. These last features indicate at first close morphological affinities of CPUC/C/557 with $T$. natans. However, CPUC/C/557 presents a suite of distinctive characters: distal epiphysis slightly shifted anteriorly relative to the shaft (in lateral view; Fig. 2C), wide and deep groove surrounding medially the trochlea (Fig. 2B, D), transverse expansion of the epicondyles less pronounced than in other Thalassocnus species (except T. yaucensis).

Although recent works have demonstrated the relevance of postcranial material in the delimitation and identification of sloth species (e.g., Amson et al., 2015a, b; Haro et al., 2016; Rincón et al., 2015, 2018), others authors stated that more attention must be paid to intraspecific variation and to the quality of specimens in the recognition of diagnostic characters for erecting new taxa (De Iuliis, 2017). Based in the abundant postcranial remains of Thalassocnus littoralis some degree of intraspecific variation have been revealed, particularly differences in size related to sexual dimorphism (Amson et al., 2015a, b). To our knowledge there is no additional evidence of intraspecific variation within the other Thalassocnus spp. humerus. Mostly because in some species this bone is only known for the holotype, or a restricted number of referred specimens (Amson et al., 2015a; De los Arcos et al., 2017). Therefore, taking into account the scarcity of available material and the potential yet-poorly understood intraspecific variability among the Thalassocnus spp., especially within $T$. natans (known by only one specimen) we refer CPUC/C/557 to Thalassocnus cf. T. natans, until more materials will be recovered.

\section{Discussion}

As previously mentioned, distinct species of the aquatic sloth have been (even tentatively) reported in Chile: T. natans (Suárez et al., 2011; Pyenson et al., 2014), T. carolomartini (De los Arcos et al., 2017), a form similar to T. antiquus or T. natans (Canto et al., 2008), an intermediate form between $T$. littoralis and T. natans (Suárez et al., 2011), and a species of Thalassocnus younger than T. natans (De los Arcos et al., 2017). Most of the findings of Thalassocnus in Chile comes from the Bahía Inglesa Formation, which are based on fragmentary or not fully described materials. The first record consists in the recovery of a partial mandible referable to Thalassocnus (Canto et al., 2002). Later, these authors described in detail the specimen and suggested that is not possible to discriminate whether would belong to T. antiquus or T. natans (Canto et al., 2008). Suárez et al. (2011) mentioned the presence of two femora referred to Thalassocnus sp. (SGO.PV 1133), recovered from the "Arenas de Caldera" locality, as well as several associated bones (MPC-SPN2), including a skull, some vertebrae and ribs, an ulna-radius complex, a fragment of pelvis, and two femora. The later material indicating the presence of at least two individuals. According to Suárez et al. (2011), the MPC-SPN2 femurs shows a remarkable affinity to those of $T$. natans, while the ulna-radius complex shows intermediate characteristics between $T$. natans and T. littoralis. Thus, the materials of Suárez et al. (2011) cannot be clearly refereed to other taxa than T. natans or T. littoralis, until a fully description of the MPC-SPN2 specimen will be performed. Other material previously attributed to $T$. natans consists of a complete femur and a fragmentary mandible (not associated) recovered from the Cerro Ballena locality by Pyenson et al. (2014). According to Amson et al. (2015b), the fragmentary mandible is hardly referable to a particular species of Thalassocnus. Amson et al. (2015b) also reevaluate the taxonomic affinities of Pyenson's femur and suggest an attribution to either T. antiquus or T. natans. This scenario pointed out that from the Bahía Inglesa Formation is not clear what species, among T. antiquus, T. natans, or T. littoralis, was present (see discussion below). In other hand, in the Coquimbo Formation a partial skeleton was recovered, and assigned to T. carolomartini, while in the Horcón Formation an isolated phalanx allows for the recognition of some of the younger species than T. natans (T. littoralis, T. carolomartini and $T$. yaucensis; De los Arcos et al., 2017).

A reassess of the stratigraphic provenance of the materials previously mentioned might shed light about the diversity of Thalassocnus species inhabiting Chile during the late Neogene. The specimens reported for Pyenson et al. (2014) were recovered from the Cerro Ballena locality, which belongs to the homonymous member of the Bahía Inglesa Formation (sensu Le Roux et al., 2016). Based on the putative presence of T. natans and shark fossils (Carcharodon hastalis), which occur together in beds of this age in the Sacaco area of Perú, Pyenson et al. (2014) assigned a late Miocene age (9.03-6.45 Ma) to this member. A more recent revision of the chronostratigraphic framework 
of the Bahía Inglesa Formation, bracket the age of the Cerro Ballena Member to an age around 8.4 Ma (Le Roux et al., 2016). This confirm the suspects of Amson et al. (2015b) about the possible temporal correlations between the Cerro Ballena Member (8.4 Ma; Bahía Inglesa) and the Aguada de Lomas horizon (8-8.8 Ma; Pisco Formation). Only based in the biochron of each Thalassocnus recognized in the Pisco Formation, the last suggests that the specimens initially recognized as $T$. natans (Pyenson et al., 2014), and either T. antiquus or T. natans (Amson et al., 2015b), may indeed belongs to the older species, T. antiquus (Amson et al., 2015b). But as clearly stated by De Iuliis (2017) taxa should be diagnosed on morphology, not age or geographic provenance.

The specimen SGO.PV 1133 (Thalassocnus sp.) is from the "Arenas de Caldera" locality (Morro Member sensu Walsh and Suárez, 2005), which according to the new stratigraphic framework of Le Roux et al. (2016) represent either the top of the Cerro Ballena Member or the base of the La Higuera Member. The age of this remains (SGO. PV 1133) is therefore constrains between 8.1-8.4 Ma (Le Roux et al., 2016). The specimen referred to T. antiquus or T. natans by Canto et al. (2008) is from the Mina Fosforita Member (sensu Le Roux et al., 2016) of ca. 7.0 Ma, a similar stratigraphic provenance of the materials here described, as well as those of Suárez et al. (2011). All the materials recovered from the Mina Fosforita Member shows morphological affinities with $T$. natans, including the specimen here described. The recognition of this taxa is not ascertained (see discussion above), but its presence has biochronological congruence with the known fossil record of the species in Perú. No younger records of Thalassocnus than those of the Mina Fosforita Member have been made from the Bahía Inglesa Formation, constraining the record of the genus in this Formation to 8.4-7 Ma (Late Miocene).

Specimens referred to Thalassocnus carolomartini have been recovered from the Coquimbo Formation (Lomas del Sauce locality), which is likely Pliocene age (De los Arcos et al., 2017). The other Thalassocnus specimen reported by De los Arcos et al. (2017), belongs to a species younger that $T$. natans (T. littoralis, T. carolomartini or T. yaucensis), was recovered from the Horcón Formation (Playa La Luna locality) with a late Pliocene age (Carrillo-Briceño et al., 2013). Again, only based in the biochronological intervals recognized from Thalassocnus spp. from the Pisco Formation
(Perú), the materials from the Horcón Formation must have closer affinities to T. yaucensis. But in any case, the specimen from the Horcón Formation represents the younger record of the genus in Chile and probably the last fossil record of the genus.

\section{Conclusions}

As previously discussed, only few Thalassocnus specimens recovered from Chile have been described and/or illustrated in details (Canto et al., 2008; De los Arcos et al., 2017). A review of the finding so far mentioned as well as the new evidence here presented, allow us to propose that the taxonomic diversity of Thalassocnus in Chile might include at least two distinct species, T. carolomartini (De los Arcos et al., 2017), and T. natans (present work). However, the stratigraphic provenance of other specimens suggests a higher taxonomic diversity which could reach up to four species, with the addition of T. antiquus (Amson et al., 2015b) and probably T. yaucensis (De los Arcos et al., 2017).

Finally, the present work contributes to delineate the still poorly studied diversity of fossil mammals in Chile, and particularly of sloths. Future discoveries of more complete Chilean specimens (which include cranial and postcranial elements) in a clear chronostratigraphic framework, and/or the description of the partial skeleton briefly mentioned by Suárez et al. (2011), will certainly help to illustrate the evolutionary history of the Thalassocnus radiation in Chile.

\section{Acknowledgements}

G. Flores (UDEC) is thanked for allowing the study of the material and giving access to the collection of the Geological Museum Lajos Biró Bagóczky. M. Suárez kindly provide valuable information regarding the stratigraphic provenance of the studied specimen. A. Saldaña and S. Palma Heldt (UDEC) provides logistical advice and support. Finally, we thank C. de Muizon, S. De los Arcos and W. Vivallo for their comments and suggestions that improved the quality of the manuscript. AS acknowledges partial support from CONICYT-PCHA/ Doctorado Nacional/2018- 21180471.

\section{References}

Achurra, L. 2004. Cambios del nivel del mar y evolución tectónica de la cuenca Neógena de Caldera, III Región. 
Tesis de Magíster (Inédito), Universidad de Chile, Departamento de Geología: 138 p.

Amson, E.; Muizon, C.; Laurin, M; Argot, C.; Buffrénil V. 2014. Gradual adaptation of bone structure to aquatic lifestyle in extinct sloths from Perú. Proceedings of the Royal Society of London B, Biological Sciences 281 (1782): 1-6. doi: 10.1098/rspb.2014.0192.

Amson E.; Argot, C.; McDonald, H.G.; De Muizon, C. 2015a. Osteology and functional morphology of the forelimb of the marine sloth Thalassocnus (Mammalia, Tardigrada). Journal of Mammalian Evolution 22 (2): 169-242.

Amson, E.; Argot, C.; McDonald, H.G.; De Muizon, C. 2015b. Osteology and functional morphology of the hind limb of the marine sloth Thalassocnus (Mammalia, Tardigrada). Journal of Mammalian Evolution 22 (3): 355-419.

Amson, E.; Argot, C.; McDonald, H.G.; De Muizon, C. 2015c. Osteology and functional morphology of the axial postcranium of the marine sloth Thalassocnus (Mammalia, Tardigrada) with paleobiological implications. Journal of Mammalian Evolution 22 (4): 473-518.

Amson, E.; De Muizon, C.; Gaudin, T.J. 2016. A reappraisal of the phylogeny of the Megatheria (Mammalia: Tardigrada), with an emphasis on the relationships of the Thalassocninae, the marine sloths. Zoological Journal of the Linnean Society 179 (1): 217-236.

Bargo, S.; Vizcaíno, S.; Archuby, F.; Blanco, E. 2000. Limb bone proportions, strength and digging in some Lujanian (Late Pleistocene-Early Holocene) mylodontid ground sloths (Mammalia, Xenarthra). Journal of Vertebrate Paleontology 20 (3): 601-610.

Bianucci, G.; Di Celma, C.; Landini, W.; Post, K.; Tinelli, C.; Muizon, C. de; Gariboldi, K.; Malinverno, E.; Cantalamessa, G.; Gioncada,A.; Collareta,A.; Salas-Gismondi, R.; Varas-Malca, R.; Urbina, M.; Lambert, O. 2016. Distribution of fossil marine vertebrates in Cerro Colorado, the type locality of the giant raptorial sperm whale Livyatan melvillei (Miocene, Pisco Formation, Perú). Journal of Maps 12 (3): 543-557.

Canto, J.; Yáñez, J.; Cozzuol, M.A. 2002. Mamíferos marinos neógenos de la Formación Bahía Inglesa, Caldera, III Región, Chile. In Congreso Latinoamericano de Paleontología de Vertebrados, No. 1, Actas: 22. Santiago.

Canto, J.; Salas-Gismondi, R.; Cozzuol, M.; Yáñez, J. 2008. The aquatic sloth Thalassocnus (Mammalia, Xenarthra) from the late Miocene of north-central Chile: biogeographic and ecological implications. Journal of Vertebrate Paleontology 28 (3): 918-922.
Chávez, F.M. 2007. Sobre la presencia de Paraptenodytes y Palaeospheniscus (Aves: Sphenisciformes) en la Formación Bahía Inglesa, Chile. Revista Chilena de Historia Natural 80 (2): 255-259.

Chávez, F.M. 2008. La Ornitofauna de la Formación Bahía Inglesa, Caldera, Chile. Memoria de Título (Inédito), Universidad Austral de Chile, Facultad de Ciencias: 88 p.

Carrillo-Briceño, J.D.; González-Barba, G.; Landaeta, M.F.; Nielsen, S. 2013. Condrictios fósiles del Plioceno Superior de la Formación Horcón, Región de Valparaíso, Chile central. Revista Chilena de Historia Natural 86 (2): 191-206.

De los Arcos, S.; Partarrieu, D.; Carrillo-Briceño, J.; Amson, E. 2017. The southernmost occurrence of the aquatic sloth Thalassocnus (Mammalia, Tardigrada) from two new localities of the Pliocene of Chile. Ameghiniana 54 (4): 351-369.

De Iuliis, G. 2017. Recent progress and future prospects in fossil xenarthran studies, with emphasis on current methodology in sloth taxonomy. Journal of Mammalian Evolution 25 (3). doi: 10.1007/s10914-017-9407-8.

Fariña, R.A.; Blanco, R.E. 1996. Megatherium, the stabber. Proceedings of the Royal Society of London B 263 (1377): 1725-1729.

Gaudin, T.J.; Croft, D.A. 2015. Paleogene Xenarthra and the evolution of South American mammals. Journal of Mammalogy 96 (4): 622-634.

Godoy, E.; Marquardt, C.; Blanco, N. 2003. Carta Caldera, Región de Atacama. Servicio Nacional de Geología y Minería, Carta Geológica de Chile, Serie Geología Básica 76: 38 p. Santiago.

Haro, J.A.; Tauber, A.A.; Krapovickas, J.M. 2016. The manus of Mylodon darwinii Owen (Tardigrada, Mylodontidae) and its phylogenetic implications. Journal of Vertebrate Paleontology 36 (5): e1188824. doi: 10.1080/02724634.2016.1188824.

Le Roux, J.P.; Achurra, L.; Henríquez, Á.; Carreño, C.; Rivera, H.; Suárez, M.E.; Gutstein, C.S. 2016. Oroclinal bending of the Juan Fernández Ridge suggested by geohistory analysis of the Bahía Inglesa Formation, north-central Chile. Sedimentary Geology 333: 32-49.

Marchant, M.; Marquardt, C.; Blanco, N.; Godoy, E. 2000. Foraminíferos del área de Caldera $\left(26^{\circ} 45-28^{\circ} \mathrm{S}\right)$ y su utilización como indicadores cronoestratigráficos del Neógeno. In Congreso Geológico Chileno, No. 9, Actas: 499-503. Puerto Varas.

Marquardt, C.; Blanco, N.; Godoy, E.; Alavenu, L.; Marchant, M.; Guzmán, N. 2000. Estratigrafía del Cenozoico superior en el área de Caldera $\left(26^{\circ} 45^{\prime}-28^{\circ} \mathrm{S}\right)$. In Congreso 
Geológico Chileno, No. 9, Actas: 588-592. Puerto Varas.

McDonald, H.G. 2005. Paleoecology of extinct xenarthrans and the great American biotic interchange. Bulletin of the Florida Museum of Natural History 45 (4): 313-333.

McDonald, H.G.; De Muizon, C. 2002. The cranial anatomy of Thalassocnus (Xenarthra, Mammalia), a derived nothrothere from the Neogene of Pisco Formation (Perú). Journal of Vertebrate Paleontology 22 (2): 349-365.

McDonald, H.G.; De Iuliis, G. 2008. Fossil history of sloths. In Biology of the Xenarthra. (Vicaíno, S.F.; Loughry, W.J.; editors). University Press of Florida: 39-55. Gainesville.

McKenna, M.C.; Bell, S.K. 1997. Classification of Mammals above the Species Level. Casebound editions of Columbia University Press: 547. New York.

McKenna, M.C.; Wyss, A.R.; Flynn, J.J. 2006. Paleogene pseudoglyptodont xenarthrans from Central Chile and Argentine Patagonia. American Museum Novitates 3536: 1-18.

Muizon, C.; DeVries, T.J. 1985. Geology and paleontology of Late Cenozoic marine deposits in the Sacaco area (Perú). Geologische Rundschau 74 (3): 547-563.

Muizon, C.; McDonald, H.G. 1995. An aquatic sloth from the Pliocene of Perú. Nature 375 (6528): 224-227.

Muizon, C.; McDonald, H.G.; Salas, R.; Urbina, M. 2003. A new early species of the aquatic sloth Thalassocnus (Mammalia, Xenarthra) from the late Miocene of Perú. Journal of Vertebrate Paleontology 23 (4): 886-894.

Muizon, C.; McDonald, H.G.; Salas, R.; Urbina, M. 2004a. The Evolution of Feeding Adaptation of the Aquatic Sloth Thalassocnus. Journal of Vertebrate Paleontology 24 (2): 398-410.

Muizon, C.; McDonald, H.G.; Salas, R.; Urbina, M. 2004b. The youngest species of the sloth Thalassocnus and a reassessment of the relationships of the sloths (Mammalia: Xenarthra). Journal of Vertebrate Paleontology 24 (2): 387-397.

Pujos, F.; De Iuliis, G.; Werdelin, L. 2007. A peculiar climbing Megalonychidae from the Pleistocene of Perú and its implication for sloth history. Zoological Journal of the Linnean Society 149 (2): 179-235.

Pyenson, N.D.; Gutstein, C.S.; Parham, J.F.; Le Roux, J.P.; Chavarrı, C.C.; Little, H.; Metallo, A.; Rossi, V.; Valenzuela-Toro, A.M.; Vélez-Juarbe, J.; Santelli, C.M.; Rogers, D.R.; Cozzuol, M.A.; Suárez, M.E. 2014. Repeated mass strandings of Miocene marine mammals from Atacama Region of Chile point to sudden death at sea. Proceedings of the Royal Society B 281 (1781): 20133316. doi: 10.1098/rspb.2013.3316.

Rincón, A.D.; McDonald, H.G.; Solórzano, A.; NúñezFlores, M.; Ruiz-Ramoni, D. 2015. A new enigmatic Late Miocene mylodontoid sloth from northern South America. Royal Society Open Science 2 (2): p. 140256. doi: 10.1098/rsos.140256.

Rincón, A.D.; Solórzano, A.; McDonald, H.G.; MontellanoBallesteros, M. 2018. Two new megalonychid sloths (Mammalia: Xenarthra) from the Urumaco Formation (late Miocene), and their phylogenetic affinities. Journal of Systematic Palaeontology 17 (5): 409-421. doi: 10.1080/14772019.2018.1427639.

Shockey, B.J.; Anaya, F. 2011. Grazing in a new late Oligocene mylodontid sloth and a mylodontid radiation as a component of the Eocene Oligocene faunal turnover and the early spread of grasslands/ savannas in South America. Journal Mammal Evolution 18 (2): 101-115.

Suárez, M.E.; Lamilla, J.; Marquardt, C. 2004. Peces Chimaeriformes (Chondrichthyes, Holocephali) del Neógeno de la Formación Bahía Inglesa (Región de Atacama, Chile). Revista Geológica de Chile 31 (1): 104-118. doi: 10.5027/andgeoV31n1-a06.

Suárez, M.E.; Valenzuela-Toro, A.; Gutstein, C.S.; Cozzuol, M.; Pyenson, N. 2011. Nuevos restos de Thalassocnus (Nothrotheriidae, Thalassocninae) del neógeno de la Formación Bahía Inglesa, Región de Atacama, Norte de Chile. Ameghiniana 48 (4): 212-213.

Toledo, N.; Cassini, G.H.; Vizcaíno, S.F.; Bargo, M.S. 2014. Mass estimation of Santacrucian sloths from the early Miocene Santa Cruz Formation of Patagonia, Argentina. Acta Palaeontologica Polonica 59 (2): 267-280.

Vizcaíno, S.F.; Loughry, W.J. 2008. Biology of the Xenarthra. University Press of Florida: 39-55. Gainesville.

Walsh, S.A.; Hume, P.J. 2001. A new Neogene marine Avian assemblage from north-central Chile. Journal of Vertebrate Paleontology 21 (3): 484-491.

Walsh, S.A.; Suárez, M. 2005. First post-Mesozoic record of Crocodyliformes from Chile. Acta Paleontologica Polonica 50 (3): 595-600.

White, J.L. 1997. Locomotor adaptations in Miocene xenarthrans. In Vertebrate Paleontology in the Neotropics, the Miocene Fauna of La Venta, Colombia (Kay, R.F.; Madden, R.H.; Cifelli, R.L.; Flynn, J.J.; editors). Smithsonian Institution Press: 246-264. Washington.

Wilson, D.E.; Reeder, D.M. 2005. Mammal species of the world: a taxonomic and geographic reference. The Johns Hopkins University Press: 2142 p. Baltimore.

$\overline{\text { Manuscript received: July 13, 2018; revised/accepted: November 27, 2018; available online: February 04, } 2019 .}$ 